\title{
Typologie voliče pro komunální volby
}

\author{
Typology of Voters in Municipal Elections \\ Vojtěch Spáčil
}

\begin{abstract}
This contribution is interested in the most suitable segmentation criteria for use in voter classification. The theoretical background section discusses some approaches to voter segmentation (e.g., age, income, attitudes to elections). Practically speaking, voters are often segmented based on political party preference or demographic variables such as gender, age, education and social status. This paper classifies voters in municipal elections according to their perceptions of problems in their neighbourhoods and towns. This represents an example of behavioural segmentation criteria. Through hierarchical cluster analysis the typology of voters was constructed. Knowledge of problems and voters' desires is necessary for setting election programs and crafting persuasive messages. Statistical testing has confirmed the relationship between this typology and demographic and geographic variables, which helps politicians to identify the voter base and adjust their use of media tools.
\end{abstract}

KEY WORDS typology of voters, municipal elections, segmentation criteria, electoral preferences, cluster analysis

\section{Úvod}

Segmentace je nezbytnou procedurou marketingového plánování a řízení. Nalezení rozdílů v potřebách zákazníků, uspořádání zákazníků do skupin podle podobnosti těchto potřeb a jejich následné uspokojení je obecně důležité pro budování konkurenceschopnosti ekonomických subjektů. Politické subjekty si rovněž uvědomují významnost marketingu pro dosažení svých politických cílů. Hlavní marketingové úsilí politických stran se soustřed’uje na intenzivní komunikaci a sledování volebních preferencí prostřednictvím marketingových výzkumů. Problematika praktické segmentace je většinou spojována s identifikací demografického profilu voličů jednotlivých politických stran. Tento prŕspěvek se pokouší identifikovat vliv i jiných segmentačních proměnných.

Sociálni studia. Katedra sociologie FSS MU, 3/2011. S. 15-37. ISSN 1214-813X. 


\section{Současný stav řešené problematiky}

Segmentace zákazníků je obecně používána pro analýzu a identifikaci skupin zákazníků s podobnými charakteristikami, které jsou vnímány jako nejdůležitější (Wedel a Kamakura 2000). Na spotřebitelských i průmyslových trzích je možné identifikovat řadu rozdílů v geografii, demografii, firmografii, nákupním chování, rozhodovacích procesech, nákupních přístupech, situačních faktorech, osobnosti, životním stylu, psychografii a podobně (Aaker 2007, Bonoma a Shapiro 1984, Bock a Uncles 2002).

Význam segmentace pro politickou komunikaci a pro budování pozice (positioning) strany na volebním trhu je ilustrován ve studii Harropa (1990). Stejně tak je často používán systém ACORN ${ }^{1}$ jako segmentační báze pro zacílení na voliče (Yorke a Meehan 1986).

Obecně není možné předpokládat, že všichni voliči postupují při rozhodování o způsobu hlasování ve volbách stejně. Je spíše pravděpodobné, že se voliči rozhodují kvalitativně jiným způsobem, hodnotí podle rozdílných kritérií, použivají alternativní zdroje informací a postupují různými cestami pro dosažení stejného výsledku (jako je výběr dané politické strany z volebního seznamu). Sniderman, Brody a Tetlock (1991) si uvědomili heterogenitu voličů a navrhli vlastní klasifikaci voličů.

Existuje mnoho způsobů a kritérií pro segmentaci voličů. Jedním z klíčových segmentačních kritérií je věk, který patří k demografickým proměnným. Protože populace ve vyspělých demokraciích stárne, lze očekávat, že skupina seniorů, kteří obvykle vykazují tendenci k účasti ve volbách, roste jak relativně, tak absolutně. Vzhledem k intenzivní volební účasti a demografickému podílu mají starší voliči fundamentální dopad na volební výsledky (Goerres 2008). Jak se liší starší voliči od mladších s ohledem na jejich výběr politické strany? Na jedné straně patři obě skupiny do rozdílných generací, které nesdílejí politické preference z důvodu svých rozdílných životních zkušeností, na druhé straně se dané věkové skupiny nacházejí v rozdílných fázích životního cyklu, což je faktor působící na jejich politické zájmy. Mnoho hypotéz vycházejících z teorie životního cyklu předpokládá, že lidé se s věkem stávají konzervativními (Glenn a Hefner 1972). Konzervatismus se projevuje dvěma způsoby: za prvé se občané stávají v průběhu času ekonomicky konzervativnějšími, nebot' nashromáždili více materiálních statků, které chtějí uchovat (Binstock a Quadagno 2011), za druhé se starší lidé stávají autoritativními (Tilley 2005). Jiná hypotéza životního cyklu byla definována Barnesem (1999). Tak, jak volič stárne, vykazuje sklon volit strany, které jsou velké a pravidelně se objevují v parlamentu nebo zastupitelstvu. Menší strany jsou u starších voličů v nevýhodě, protože voliči je neznají a nemají odvahu jim dát hlas.

Jiné významné demografické kritérium, které má vliv na rozhodování na volebním trhu, je prŕjjem voliče. Model mediánového (středního) voliče má dlouhou teoretickou a empirickou historii v rámci veřejné ekonomie. Pionýrskou práci představuje model Bergstroma a Goodmana (1973), kteří prokázali, že střední volič je volič s mediánovým př́ijmem. Desítky studií použily koncept středního voliče k odhadu poptávek po veřejných statcích a službách. Epple a Romano (1996) ukázali, že tam, kde existují privátní alternativy k veřejným statkům nebo $\mathrm{v}$ př́padě, že veřejné statky mohou být doplněny o privátní nákupy, vznikne rovnováha

ACORN je geodemografická segmentace britské populace, která klasifikuje domácnosti do 5 kategorií, 17 skupin a 56 typů. 
tehdy, když má klíčový volič př́ijem těsně pod mediánem. Vytrvalá popularita tohoto modelu pramení z jeho jednoduchosti a jeho analytické přizpůsobivosti. Epple a Platt (1998) později rozvinuli model, který jednoznačně zdůvodnil tř́íění domácností podle preferencí, a demonstrovali, že pokud se domácnosti liší podle příjmu a preferencí, volič s mediánovým př́ijmem není klíčový. Epple a Sieg (1999) a Epple (2001) sestavili strukturální modely, které připouští heterogenitu v preferencích a umožňují odhad př́jmových elasticit v modelu, který jasně identifikuje voliče s mediánovou preferencí. Jejich výsledky prokazují podstatnou heterogenitu preferencí v rámci komunit a zdůvodňují, že volič s mediánovou preferencí není pravděpodobně voličem s mediánovým př́imem. Brunner a Ross (2010) zjištovali, zda je volič s mediánovým př́ijmem důležitý pro rozhodování o lokálních (municipálních) výdajích. Na základě empirického důkazu bylo potvrzeno, že percentil příjmu nižšśi než medián je rozhodující pro většinu volebních situací, zvláště v komunitách, které mají vysoký podíl voličů s vyšším př́ijmem s atributy, které naznačují nízkou poptávku po veřejných službách. Prostřednictvím jejich modelu je možné jednoznačně prokázat, že každá komunita obsahuje voliče s vysokou a nízkou poptávkou po výdajích na veřejné školství.

Diskusi $\mathrm{k}$ problematice postojů lze vést i z pohledu př́ípadné účasti ve volbách, což je rovněž jiná forma behaviorální proměnné. Teorie pracuje s konceptem nerozhodnutého voliče. Nerozhodnutý volič je takový respondent, který při výzkumu volebních preferencí před konáním voleb není schopen vyjádřit svůj názor na preferovanou politickou stranu nebo popsat svůj postoj k účasti ve volbách. Existují tři pravděpodobné důvody, které způsobují nerozhodnost voličů. Prvním důvodem je, že nerozhodnutý volič se nezajímá o politiku ve střednědobé perspektivě, a proto ignoruje přesvědčující sdělení. Druhý a třetí důvod je výsledkem bud' slabých neoslovujících sdělení, nebo výsledkem př́lišné agresivity sdělení, která voliče odrazuje (Kosmidis a Xezonakis 2010).

\section{Metodika výzkumu}

Cílem výzkumu bylo identifikovat preference voličů v komunálních volbách a prostřednictvím shlukové analýzy definovat segmenty potencionálních voličů. Záměrem bylo určit, zda lze nalézt shluky respondentů, kteří vnímají problémy města či okolí bydliště podobným způsobem, a zda lze najít problémy, které mají pro respondenty podobný charakter. Úkolem bylo vytvořit typologii voličů, která by byla založena na identifikovaných problémech, u kterých by respondenti očekávali, že je vyřeší politická strana či seskupení kandidující v komunálních volbách. Identifikované (nebo intenzivně vnímané) problémy okolí bydliště nebo města představují typ behaviorální segmentační proměnné, která obecně vypovídá o postojích, názorech či chování zákazníků - voličů.

Předmětem analýzy bylo také zkoumání toho, zda se demografické proměnné (pohlaví, věk, vzdělání, preference politické strany) promítají do struktury jednotlivých typů voličů. To lze formulovat prostřednictvím pěti nulových hypotéz:

Nulová hypotéza A: Struktura shluků na základě vnímání problémových oblastí nezávisí na pohlaví. 
Nulová hypotéza B: Struktura shluků na základě vnímání problémových oblastí nezávisí na věku.

Nulová hypotéza C: Struktura shluků na základě vnímání problémových oblastí nezávisí na vzdělání.

Nulová hypotéza D: Struktura shluků na základě vnímání problémových oblastí nezávisí na preferenci volební strany.

Nulová hypotéza E: Struktura shluků na základě vnímání problémových oblastí nezávisí na městě šetření.

Pro identifikaci intenzivních problémů byl respondentům nejprve předložen soubor faktorů, které se týkají okolí (ulice), ve kterém respondenti bydlí, a tito byli požádáni, aby vybrali z uvedeného přehledu tři nejdůležitější problémy vyskytující se v okolí (ulice) bydliště $\mathrm{s}$ uvedením pořadí jejich významnosti. Otázka byla přesně formulována následujícím způsobem: „Nyní Vám nabídnu několik problémů, které se mohou ve Vašem okolí bydliště (v ulici) vyskytovat. Vyberte z uvedeného přehledu tři nejdůležitější problémy vyskytující se ve Vašem okolí. Označte z uvedeného seznamu nejdůležitější problém, druhý nejdůležitější problém a třetí nejdůležitější problém." Respondenti posuzovali významnost u následujících faktorů:

- bezpečnost,

- parkování,

- nedostatek dětských hřišt',

- hluk,

- nepoŕádek,

- dopravní situace,

- nedostatek sportovišt',

- dostupnost MHD,

- kvalita ovzduší,

- kvalita zelených ploch,

- nedostatek obchodů se základními potřebami.

Respondentům byl rovněž předložen soubor problémů, které se týkají celého města, a byli vyzváni, aby vybrali z uvedeného přehledu tři nejdůležitější problémy vyskytující se $\mathrm{v}$ daném městě $\mathrm{s}$ uvedením pořadí jejich významnosti. Otázka byla přesně formulována následujícím způsobem: „Nyní Vám předložím soubor problémů, které se týkají celé Ostravy (Havírova). Co považujete za největší problém celé Ostravy (Havírova)? Vyberte z uvedeného přehledu tř̌i nejdůležitější problémy vyskytující se v Ostravě (Haviŕrově). Označte z uvedeného seznamu nejdůležitější problém, druhý nejdůležitější problém a třetí nejdůležitější problém.“ Přehled faktorů pro ohodnocení významnosti byl následující:

- bezpečnost,

- parkování,

- odchod kvalifikovaných lidí z města,

- hluk,

- kvalita zdravotní péče, 
- korupce,

- neprůhledné hospodaření radnice,

- nepořádek,

- kvalita zelených ploch,

- kvalita ovzduší,

- nedostatek dětských hřišt',

- dopravní situace.

V obou případech byla získána ordinální proměnná, která byla kódovaná tak, že faktor (problém), který byl zmíněn respondenty na prvním místě - jako nejdůležitější -, získal čtyři body. Problém uvedený jako druhý nejdůležitější byl oceněn třemi body a faktor vnímaný jako třetí nejdůležitější byl ohodnocen dvěma body. Problémy, které respondenty zmíněny nebyly, byly pro účely aplikace shlukové analýzy oceněny jedním bodem.

Jak bylo právě naznačeno, typologie voličů byla řešena prostřednictvím metody shlukové analýzy. Pro vyřešení problému marketingové segmentace existuje mnoho shlukových metod, které je možné rozdělit na hierarchické a nehierachické (Kuo, Ho a Hu 2002). Z mnoha vhodných metod byla vybrána hierarchická shluková analýza (aglomerativní shlukování), která je založena na tvorbě hierarchie nebo stromové struktuře. Shlukování začíná tím, že každý respondent (objekt) stojí samostatně a potom je postupně seskupován s ostatními do větších a větších shluků. Tento proces aglomerativního shlukování probíhá tak dlouho, až jsou všichni respondenti (členové) součástí jednoho shluku. Pro účely studie byla zvolena metoda nejbližšího souseda (single linkage method), která vychází z pravidla minimální vzdálenosti mezi dvěma objekty shluku. Jako první jsou shlukovány subjekty, mezi nimiž je nejkratší vzdálenost. Po identifikaci další nejkratší vzdálenosti je třetí objekt bud' shlukován s prvními dvěma, nebo je vytvořen nový shluk ze dvou nejbližších objektů. $\mathrm{Na}$ každém stupni je vzdálenost mezi dvěma shluky vzdáleností mezi dvěma nejbližšími body (Malhotra a Birks 2006).

Data pro typologii voliče byla založena na dvou reprezentativních primárních šetřeních. První proběhlo v roce 2006 v Ostravě, druhé šetření se uskutečnilo v roce 2010 v Havířově. Výběr měst byl záměrný s ohledem na to, že na jednu stranu vykazují shodu v tom, že leží v Moravskoslezském kraji ve vzdálenosti dvacet km od sebe patří mezi původně hornická města s vysokým podílem imigrantů a počtem obyvatel obě převyšují 80000 . Na druhou stranu mají obě města rozdílnou historii (Havířov byl založen až v roce 1955), mají rozdílnou infrastrukturu a především rozdílné politické zabarvení, což je klíčové pro potřeby výzkumu. Na základě volby dvou míst pro realizaci primárních šetření je možné formulovat hypotézu:

Nulová hypotéza F: Mezi vnímáním problémových oblastí ve sledovaných městech neexistuje rozdíl.

Ačkoliv zkoumaná šetření dělí čtyři roky, na základě práce Kahnemana a Tverského (1972) lze předpokládat, že heuristika, která je předpokládaná u voliče, je v prostoru a čase neměnná. Vychází se přitom z předpokladu, že při zkoumání, zda objekt nebo událost A patří do trrídy nebo procesu $\mathrm{B}$, je pravděpodobnost vztahu, $\mathrm{v}$ němž $\mathrm{A}$ reprezentuje $\mathrm{B}$, závislá 
na tom, zda se A podobá B. Interní konzistence vstupů (v našem případě struktura výběrových souborů) je hlavním determinantem důvěryhodnosti předpovědí (v našem př́ípadě vnímání problémových oblastí) závislých na těchto vstupech (Kahneman a Tversky 1974).

V obou případech bylo šetření realizováno tři až čtyři týdny před komunálními volbami a byla použita stejná metodika. Vzhledem $\mathrm{k}$ již probíhající volební kampani se dalo předpokládat, že respondenti byli ovlivněni obsahem a sděleními kampaní, což mohlo napomoci lepší orientaci v zadaném tématu. Data byla shromážděna prostřednictvím osobního dotazování v domácnostech respondentů. Šetření v Ostravě se zúčastnilo 749 respondentů a v Havírově 490 respondentů. Výběrový soubor byl tvořen kvótním způsobem se záměrem dodržet kvóty pro pohlaví, věk a vzdělání. Struktura výběrového souboru odráží strukturu základního souboru ve sledovaných městech a je popsána v tabulkách 1 až 3 .

Tabulka 1: Struktura výběrového souboru podle pohlaví

\begin{tabular}{|l|c|c|c|}
\hline \multirow{2}{*}{} & \multicolumn{2}{|c|}{ Město } & \multirow{2}{*}{ Celkem } \\
\cline { 2 - 3 } & Ostrava & Havĩ̃ov & \\
\hline Žena & $53 \%$ & $54 \%$ & $\mathbf{5 3 \%}$ \\
\hline Muž & $47 \%$ & $46 \%$ & $\mathbf{4 7 \%}$ \\
\hline
\end{tabular}

Tabulka 2: Struktura výběrového souboru podle věku

\begin{tabular}{|l|c|c|c|}
\hline \multirow{2}{*}{} & \multicolumn{2}{|c|}{ Město } & \multirow{2}{*}{ Celkem } \\
\cline { 2 - 3 } & Ostrava & Havĩov & \\
\hline $18-29$ & $22 \%$ & $16 \%$ & $\mathbf{2 0 \%}$ \\
\hline $30-39$ & $21 \%$ & $20 \%$ & $\mathbf{2 1 \%}$ \\
\hline $40-49$ & $20 \%$ & $20 \%$ & $\mathbf{2 0 \%}$ \\
\hline $50-59$ & $17 \%$ & $18 \%$ & $\mathbf{1 8 \%}$ \\
\hline $60+$ & $19 \%$ & $26 \%$ & $\mathbf{2 1 \%}$ \\
\hline
\end{tabular}

Tabulka 3: Struktura výběrového souboru podle vzdělání

\begin{tabular}{|l|c|c|c|}
\hline \multirow{2}{*}{} & \multicolumn{2}{|c|}{ Město } & \multirow{2}{*}{ Celkem } \\
\cline { 2 - 3 } & Ostrava & Havĩov & \\
\hline ZV, vyučen & $38 \%$ & $48 \%$ & $42 \%$ \\
\hline SŠ & $48 \%$ & $42 \%$ & $46 \%$ \\
\hline VŠ & $14 \%$ & $10 \%$ & $12 \%$ \\
\hline
\end{tabular}




\section{Analýza výsledků}

\section{Celkové vnímání problémových oblastí}

Jako nejvýznamnější problém ve svém bezprostředním okolí vnímali respondenti v obou městech parkování, kvalitu ovzduší a hluk (viz tabulka 4). U těchto faktorů byla dosažena nejvyšší průměrná hodnota, která byla získána prostř̌ednictvím ocenění ordinálního pořadí specifikovaných problémů. Hodnota průměru může ležet u sledovaných problémových oblastí v intervalu $[1 ; 4]$. Průměrná hodnota $1 \mathrm{u}$ dané problémové oblasti by odpovídala situaci, kdy ani jeden respondent nevybral danou problémovou oblast mezi třemi nejvýznamnějšími. Naopak dosažená průměrná hodnota 4 by znamenala, že všichni respondenti označili vybranou problémovou oblast jako nejvýznamnější. Platí tedy, že čím vyšší průměrné hodnoty bylo u daného faktoru dosaženo, tím intenzivněji respondenti problém vnímají.

Tabulka 4: Celkové vnímání problémových oblastí v okolí bydliště

\begin{tabular}{|l|c|c|c|}
\hline & Ostrava & Havĩ̃ov & Celkem \\
\hline Parkování & 1,97 & 1,72 & 1,87 \\
\hline Kvalita ovzduší & 1,60 & 1,95 & 1,74 \\
\hline Hluk & 1,81 & 1,62 & 1,73 \\
\hline Nepořádek & 1,78 & 1,49 & 1,66 \\
\hline Bezpečnost & 1,71 & 1,47 & 1,62 \\
\hline Dopravní situace & 1,42 & 1,44 & 1,43 \\
\hline Nedostatek dětských hřišł & 1,54 & 1,20 & 1,41 \\
\hline Kvalita zeleně & 1,31 & 1,32 & 1,31 \\
\hline Nedostatek sportoviši & 1,39 & 1,11 & 1,28 \\
\hline Dostupnost MHD & 1,15 & 1,44 & 1,26 \\
\hline Nedostatek obchodů & 1,18 & 1,11 & 1,15 \\
\hline
\end{tabular}

Mezi výsledky dosaženými v Ostravě a Havířově jsou výrazné rozdíly, které potvrdil test rozptylu ANOVA (viz tabulka 5). Hodnota $\mathrm{F}$ vyjadřuje podíl dvou kvadrátů průměrů pro daný faktor (problém) získaný v Ostravě a Havírově. Pokud je hodnota $\mathrm{F}$ vysoká a hodnota koeficientu významnosti (p hodnota) nižší než 0,05 (hladina významnosti $95 \%$ ), může být odmítnuta nulová hypotéza, že mezi vnímáním problémových oblastí ve sledovaných městech neexistuje rozdíl, a přijata alternativní hypotéza, že tento rozdíl existuje. Nízká hodnota koeficientu významnosti navíc indikuje, že výsledky nemají náhodný charakter. Lze tak konstatovat, že až na kvalitu zeleně a dopravní situaci jsou problémy obou měst vnímány s různou naléhavostí (viz tabulka 5). V Ostravě bylo jako nejvýznamnější problém identifikováno parkování, hluk a nepořádek. V Havírově byla za největší problém označena kvalita ovzduší. Kvalita ovzduší je ovšem problémová i v Ostravě. Pokud by výzkum proběhl v roce 2010, byla by vzhledem ke zhoršující se situaci v oblasti životního prostředí v Ostravě ekologie jistě více akcentována. 
Tabulka 5: ANOVA test na celkové vnímání problémových oblastí v okolí bydliště

ANOVA

\begin{tabular}{|c|c|c|c|c|c|c|}
\hline & & $\begin{array}{l}\text { Součet } \\
\text { čtverců }\end{array}$ & $\begin{array}{l}\text { Stupeň } \\
\text { volnosti }\end{array}$ & $\begin{array}{l}\text { Průměrný } \\
\text { čtverec }\end{array}$ & F hodnota & p hodnota \\
\hline \multirow[t]{3}{*}{ Bezpečnost } & mezi skupinami & 17,178 & 1 & 17,178 & 15,232 &, 000 \\
\hline & uvnitř skupin & 1395,012 & 1237 & 1,128 & & \\
\hline & celkem & 1412,190 & 1238 & & & \\
\hline \multirow[t]{3}{*}{ Parkování } & mezi skupinami & 17,752 & 1 & 17,752 & 13,968 &, 000 \\
\hline & uvnitř skupin & 1572,100 & 1237 & 1,271 & & \\
\hline & celkem & 1589,851 & 1238 & & & \\
\hline \multirow{3}{*}{$\begin{array}{l}\text { Nedostatek } \\
\text { dětských hřišt }\end{array}$} & mezi skupinami & 33,710 & 1 & 33,710 & 43,843 &, 000 \\
\hline & uvnitř skupin & 951,086 & 1237 & ,769 & & \\
\hline & celkem & 984,796 & 1238 & & & \\
\hline \multirow[t]{3}{*}{ Hluk } & mezi skupinami & 10,623 & 1 & 10,623 & 9,578 &, 002 \\
\hline & uvnitř skupin & 1371,950 & 1237 & 1,109 & & \\
\hline & celkem & 1382,573 & 1238 & & & \\
\hline \multirow[t]{3}{*}{ Nepořádek } & mezi skupinami & 24,667 & 1 & 24,667 & 23,406 &, 000 \\
\hline & uvnitř skupin & 1303,659 & 1237 & 1,054 & & \\
\hline & celkem & 1328,326 & 1238 & & & \\
\hline \multirow{3}{*}{$\begin{array}{l}\text { Dopravní } \\
\text { situace }\end{array}$} & mezi skupinami &, 065 & 1 &, 065 &, 082 & ,774 \\
\hline & uvnitř skupin & 979,220 & 1237 & ,792 & & \\
\hline & celkem & 979,285 & 1238 & & & \\
\hline \multirow{3}{*}{$\begin{array}{l}\text { Nedostatek } \\
\text { sportovišt }\end{array}$} & mezi skupinami & 22,506 & 1 & 22,506 & 44,083 &, 000 \\
\hline & uvnitř skupin & 631,539 & 1237 & ,511 & & \\
\hline & celkem & 654,045 & 1238 & & & \\
\hline \multirow{3}{*}{$\begin{array}{l}\text { Dostupnost } \\
\text { MHD }\end{array}$} & mezi skupinami & 23,981 & 1 & 23,981 & 48,220 &, 000 \\
\hline & uvnitř skupin & 615,188 & 1237 & 497 & & \\
\hline & celkem & 639,169 & 1238 & & & \\
\hline \multirow{3}{*}{$\begin{array}{l}\text { Kvalita } \\
\text { ovzduší }\end{array}$} & mezi skupinami & 35,490 & 1 & 35,490 & 31,852 &, 000 \\
\hline & uvnitř skupin & 1378,260 & 1237 & 1,114 & & \\
\hline & celkem & 1413,750 & 1238 & & & \\
\hline \multirow[t]{3}{*}{ Kvalita zeleně } & mezi skupinami &, 033 & 1 &, 033 & ,057 & 811 \\
\hline & uvnitř skupin & 720,955 & 1237 &, 583 & & \\
\hline & celkem & 720,988 & 1238 & & & \\
\hline \multirow{3}{*}{$\begin{array}{l}\text { Nedostatek } \\
\text { obchodü }\end{array}$} & mezi skupinami & 1,479 & 1 & 1,479 & 4,390 &, 036 \\
\hline & uvnitř skupin & 416,768 & 1237 & 337 & & \\
\hline & celkem & 418,247 & 1238 & & & \\
\hline
\end{tabular}


Na stejné skupině respondentů byla zkoumána percepce problémových oblastí i v celém městě. Smysluplnost zkoumání aspektů jak v bezprostředním okolí bydliště, tak ve městě potvrzují výsledky párového srovnání průměrů prostřednictvím t testu (viz tabulky 6 a 7). Předmětem porovnání byly ty faktory, které byly zjišt’ovány jak pro bezprostřední okolí bydliště respondenta, tak pro život ve městě. Jednalo se o celkem osm faktorů hodnocených v okolí bydliště a ve městě. Rozdíly mezi vnímáním problémových oblastí v okolí bydliště a ve městě existují, což bylo statisticky prokázáno u párů $1,3,4,5$ a 6 (viz tabulka 7).

Tabulka 6: Srovnání rozdílů ve výsledcích vnímání problémů v okolí bydliště a ve městě Ostravě

Statistika párových výběrů

\begin{tabular}{|c|c|c|c|c|c|}
\hline & & Průměr & $\mathbf{N}$ & $\begin{array}{l}\text { Standardní } \\
\text { odchylka }\end{array}$ & $\begin{array}{c}\text { Standardní chyba } \\
\text { průmèru }\end{array}$ \\
\hline \multirow[t]{2}{*}{ Pár 1} & bezpečnost & 1,71 & 749 & 1,142 & 042 \\
\hline & bezpečnost ve městě & 1,89 & 749 & 1,257 & 046 \\
\hline \multirow[t]{2}{*}{ Pár 2} & parkování & 1,97 & 749 & 1,204 &, 044 \\
\hline & parkování ve městě & 1,99 & 749 & 1,191 &, 044 \\
\hline \multirow[t]{2}{*}{ Pár 3} & hluk & 1,81 & 749 & 1,108 &, 040 \\
\hline & hluk ve městě & 1,48 & 749 & 905 & 033 \\
\hline \multirow[t]{2}{*}{ Pár 4} & nepořádek & 1,78 & 749 & 1,107 & 040 \\
\hline & nepořádek ve městě & 1,60 & 749 & 977 & 036 \\
\hline \multirow[t]{2}{*}{ Pár 5} & dopravní situace & 1,42 & 749 & 883 & 032 \\
\hline & dopravní situace ve městě & 1,64 & 749 & 1,040 & 038 \\
\hline \multirow[t]{2}{*}{ Pár 6} & nedostatek sportovišf & 1,39 & 749 & 832 &, 030 \\
\hline & nedostatek hřišf ve městě & 1,27 & 749 & 705 &, 026 \\
\hline \multirow[t]{2}{*}{ Pár 7} & kvalita ovzduší & 1,60 & 749 & 993 & 036 \\
\hline & kvalita ovzduší ve městě & 1,63 & 749 & 1,024 & 037 \\
\hline \multirow[t]{2}{*}{ Pár 8} & kvalita zeleně & 1,31 & 749 & ,729 & ,027 \\
\hline & zeleň ve městě & 1,28 & 749 & 720 & ,026 \\
\hline
\end{tabular}

I přes rozdíly ve vnímání problémových oblastí v okolí bydliště a ve městě (viz tabulka 6 a 7) zůstávají nejvýznamnějšími faktory z pohledu hodnocení situace ve městě parkování i kvalita ovzduší (viz tabulka 8). Nižší hladina vnímání významnosti ekonomických problémů, jako je korupce, odchod lidí z města a hospodaření radnice, je způsobena nižší reflexí problémů v každodenním životě obyvatel města. 
Tabulka 7: Test rozdílů v průměrech párových faktorů vnímání problémů v okolí bydliště a městě Ostravě

Test párových výběrových souborů

\begin{tabular}{|c|c|c|c|c|c|c|c|c|c|}
\hline & \multicolumn{5}{|c|}{ Párové rozdíly } & \multirow{3}{*}{$t$} & \multirow{3}{*}{$\begin{array}{l}\text { Stupeň } \\
\text { volnosti }\end{array}$} & \multirow{3}{*}{ p } \\
\hline & & \multirow{2}{*}{ průmèr } & \multirow{2}{*}{$\begin{array}{c}\text { směro- } \\
\text { datná } \\
\text { odchylka }\end{array}$} & \multirow{2}{*}{$\begin{array}{l}\text { standardní } \\
\text { chyba } \\
\text { prưměru }\end{array}$} & \multicolumn{2}{|c|}{ interval } & & & \\
\hline & & & & & dolní & horní & & & \\
\hline Pár 1 & $\begin{array}{l}\text { bezpečnost } \\
\text { - bezpečnost } \\
\text { ve městě }\end{array}$ &,- 172 & 1,310 &, 048 &,- 266 &,- 078 & $-3,599$ & 748 &, 000 \\
\hline Pár 2 & $\begin{array}{l}\text { parkování } \\
\text { - parkování } \\
\text { ve městě }\end{array}$ &,- 019 & 1,293 & ,047 &,- 111 &, 074 &,- 396 & 748 & ,692 \\
\hline Pár 3 & $\begin{array}{l}\text { hluk - hluk } \\
\text { ve městě }\end{array}$ &, 324 & 1,215 &, 044 & ,237 & ,412 & 7,308 & 748 &, 000 \\
\hline Pár 4 & $\begin{array}{l}\text { nepořádek } \\
\text { - nepořádek } \\
\text { ve městě }\end{array}$ & , 178 & 1,188 &, 043 &, 092 & 263 & 4,091 & 748 &, 000 \\
\hline Pár 5 & $\begin{array}{l}\text { dopravní } \\
\text { situace - } \\
\text { dopravní } \\
\text { situace } \\
\text { ve městě }\end{array}$ &,- 216 & 1,093 &, 040 &,- 295 &,- 138 & $-5,418$ & 748 &, 000 \\
\hline Pár 6 & $\begin{array}{l}\text { nedostatek } \\
\text { sportovišt - } \\
\text { nedostatek } \\
\text { hřišt ve městě }\end{array}$ &, 120 & ,990 &, 036 &, 049 & 191 & 3,322 & 748 & 001 \\
\hline Pár 7 & $\begin{array}{l}\text { kvalita ovzduší } \\
\text { - kvalita } \\
\text { ovzduší } \\
\text { ve městě }\end{array}$ &,- 027 & 1,103 &, 040 &,- 106 & ,052 &,- 663 & 748 &, 508 \\
\hline Pár 8 & $\begin{array}{l}\text { kvalita } \\
\text { zeleně - zeleň } \\
\text { ve městě }\end{array}$ & ,029 & 872 &, 032 &,- 033 & ,092 & .921 & 748 & ,357 \\
\hline
\end{tabular}

Tabulka 8: Celkové vnímání problémových oblastí ve městě

\begin{tabular}{|l|c|c|c|}
\hline & Ostrava & Havĩov & Celkem \\
\hline Parkování ve městě & 1,99 & 1,72 & 1,88 \\
\hline Kvalita ovzduší ve městě & 1,63 & 1,86 & 1,72 \\
\hline Bezpečnost ve městě & 1,89 & 1,38 & 1,68 \\
\hline Nepořádek ve městě & 1,60 & 1,53 & 1,57 \\
\hline Dopravní situace ve městě & 1,64 & 1,43 & 1,55 \\
\hline Hluk ve městě & 1,48 & 1,62 & 1,54 \\
\hline Kvalita zdravotní péče & 1,33 & 1,29 & 1,31 \\
\hline Zeleň ve městě & 1,28 & 1,28 & 1,28 \\
\hline Korupce & 1,28 & 1,20 & 1,25 \\
\hline Odchod lidí z města & 1,25 & 1,20 & 1,23 \\
\hline Hospodaření radnice & 1,22 & 1,22 & 1,22 \\
\hline Nedostatek hřišt ve městě & 1,27 & 1,13 & 1,21 \\
\hline
\end{tabular}


Prostřednictvím testu ANOVA je možné zjistit, že rozdíly ve vnímání problémových oblastí ve městě v obou sledovaných lokalitách nejsou tak významné jako v prŕpadě problémových situací v okolí bydliště (viz tabulka 5 a 9). Nulovou hypotézu lze zamítnout v př́ípadě bezpečnosti ve městě, parkování ve městě, hluku ve městě, kvality ovzduší ve městě, nedostatku hřišt' ve městě a dopravní situace ve městě. U těchto faktorů existují rozdíly ve vnímání v Ostravě a Havířově. Největší rozdíl mezi oběma městy je patrný u bezpečnosti ve městě, která je v Ostravě podle respondentů druhým největším problémem.

Tabulka 9: ANOVA test na celkové vnímání problémových oblastí ve městě

\section{ANOVA}

\begin{tabular}{|c|c|c|c|c|c|c|}
\hline & & $\begin{array}{l}\text { Součet } \\
\text { čtverců }\end{array}$ & $\begin{array}{l}\text { Stupeň } \\
\text { volnosti }\end{array}$ & $\begin{array}{l}\text { Prưměrný } \\
\text { čtverec }\end{array}$ & F hodnota & p hodnota \\
\hline \multirow[t]{3}{*}{ Bezpečnost ve městě } & mezi skupinami & 77,349 & 1 & 77,349 & 62,445 &, 000 \\
\hline & uvnitř skupin & 1532,260 & 1237 & 1,239 & & \\
\hline & celkem & 1609,609 & 1238 & & & \\
\hline \multirow[t]{3}{*}{ Parkování ve městě } & mezi skupinami & 20,566 & 1 & 20,566 & 16,491 &, 000 \\
\hline & uvnitř skupin & 1542,698 & 1237 & 1,247 & & \\
\hline & celkem & 1563,264 & 1238 & & & \\
\hline \multirow[t]{3}{*}{ Odchod lidí z města } & mezi skupinami & ,943 & 1 & 943 & 2,016 & , 156 \\
\hline & uvnitř skupin & 578,500 & 1237 & 468 & & \\
\hline & celkem & 579,443 & 1238 & & & \\
\hline \multirow[t]{3}{*}{ Hluk ve městě } & mezi skupinami & 5,403 & 1 & 5,403 & 6,266 &, 012 \\
\hline & uvnitř skupin & 1066,676 & 1237 & ,862 & & \\
\hline & celkem & 1072,079 & 1238 & & & \\
\hline \multirow[t]{3}{*}{ Kvalita zdravotní péče } & mezi skupinami &, 301 & 1 & ,301 &, 486 &, 486 \\
\hline & uvnitř skupin & 766,194 & 1237 &, 619 & & \\
\hline & celkem & 766,496 & 1238 & & & \\
\hline \multirow[t]{3}{*}{ Korupce } & mezi skupinami & 1,910 & 1 & 1,910 & 3,738 &, 053 \\
\hline & uvnitř skupin & 632,019 & 1237 &, 511 & & \\
\hline & celkem & 633,929 & 1238 & & & \\
\hline \multirow[t]{3}{*}{ Hospodaření radnice } & mezi skupinami & ,001 & 1 &, 001 &, 001 & 970 \\
\hline & uvnitř skupin & 560,287 & 1237 & ,453 & & \\
\hline & celkem & 560,287 & 1238 & & & \\
\hline \multirow[t]{3}{*}{ Nepořádek ve městě } & mezi skupinami & 1,634 & 1 & 1,634 & 1,673 & , 196 \\
\hline & uvnitř skupin & 1207,795 & 1237 &, 976 & & \\
\hline & celkem & 1209,429 & 1238 & & & \\
\hline \multirow[t]{3}{*}{ Zeleň ve městě } & mezi skupinami &, 003 & 1 &, 003 &, 006 &, 940 \\
\hline & uvnitř skupin & 676,488 & 1237 &, 547 & & \\
\hline & celkem & 676,491 & 1238 & & & \\
\hline
\end{tabular}




\begin{tabular}{|c|c|c|c|c|c|c|}
\hline & & $\begin{array}{l}\text { Součet } \\
\text { čtverců }\end{array}$ & $\begin{array}{l}\text { Stupeň } \\
\text { volnosti }\end{array}$ & $\begin{array}{l}\text { Průmèrný } \\
\text { čtverec }\end{array}$ & F hodnota & p hodnota \\
\hline \multirow[t]{3}{*}{ Kvalita ovzduší ve městě } & mezi skupinami & 16,465 & 1 & 16,465 & 14,135 &, 000 \\
\hline & uvnitř skupin & 1440,912 & 1237 & 1,165 & & \\
\hline & celkem & 1457,377 & 1238 & & & \\
\hline \multirow{3}{*}{$\begin{array}{l}\text { Nedostatek hřišł } \\
\text { ve městě }\end{array}$} & mezi skupinami & 5,736 & 1 & 5,736 & 14,127 &, 000 \\
\hline & uvnitř skupin & 502,283 & 1237 & ,406 & & \\
\hline & celkem & 508,019 & 1238 & & & \\
\hline \multirow{3}{*}{$\begin{array}{l}\text { Dopravní situace } \\
\text { ve městě }\end{array}$} & mezi skupinami & 13,270 & 1 & 13,270 & 13,579 &, 000 \\
\hline & uvnitř skupin & 1208,803 & 1237 & 977 & & \\
\hline & celkem & 1222,073 & 1238 & & & \\
\hline
\end{tabular}

\section{Charakteristika shluků}

Prostřednictvím hierarchického shlukování byly vytvořeny shluky jak pro situaci týkající se okolí bydliště respondentů, tak pro města. Shlukování bylo realizováno ve třech variantách pro 3, 4 a 5 shluků (viz tabulka 10 a 11). Testováním byly zvoleny čtyři kategorie shluků v situaci okolí bydliště a tři kategorie shluků pro situaci ve městě.

Tabulka 10: Struktura výběrového souboru podle shluků pro okolí bydliště

\begin{tabular}{|l|c|c|c|c|c|c|}
\hline \multirow{2}{*}{} & \multicolumn{2}{|c|}{$\mathbf{5}$ shluků } & \multicolumn{2}{c|}{ 4 shluky } & \multicolumn{2}{c|}{ 3 shluky } \\
\cline { 2 - 7 } & abs.čet. & rel.čet. & abs.čet. & rel.čet. & abs.čet. & rel.čet. \\
\hline Shluk A & 887 & 71,6 & 887 & 71,6 & 1077 & 86,9 \\
\hline Shluk B & 190 & 15,3 & 190 & 15,3 & 117 & 9,4 \\
\hline Shluk C & 115 & 9,2 & 117 & 9,4 & 45 & 3,6 \\
\hline Shluk D & 45 & 3,6 & 45 & 3,6 & & \\
\hline Shluk E & 2 &, 2 & & & & 100 \\
\hline
\end{tabular}

Tabulka 11: Struktura výběrového souboru podle shluků pro město

\begin{tabular}{|l|c|c|c|c|c|c|}
\hline & \multicolumn{2}{|c|}{5 shluků } & \multicolumn{2}{c|}{ 4 shluky } & \multicolumn{2}{c|}{ 3 shluky } \\
\hline & abs.čet. & rel.čet. & abs.čet. & rel.čet. & abs.čet. & rel.čet. \\
\hline Shluk A & 756 & 61,0 & 837 & 67,6 & 889 & 71,8 \\
\hline Shluk B & 89 & 7,2 & 89 & 7,2 & 89 & 7,2 \\
\hline Shluk C & 261 & 21,1 & 261 & 21,1 & 261 & 21,1 \\
\hline Shluk D & 81 & 6,5 & 52 & 4,2 & & \\
\hline Shluk E & 52 & 4,2 & & & & 100 \\
\hline & 1239 & $\mathbf{1 0 0}$ & $\mathbf{1 2 3 9}$ & $\mathbf{1 0 0}$ & $\mathbf{1 2 3 9}$ & $\mathbf{1 0 0}$ \\
\hline
\end{tabular}


Podle hodnocení významnosti problémových oblastí v okolí bydliště je možné rozdělit respondenty (komunální voliče) do čtyř kategorií:

\section{Univerzální volič}

Typ univerzálního voliče je nejpočetnější (72\%). Jedná se o jedince, který nevnímá žádný z problémů výrazně intenzivněji než jiné. Jeho preference kvality života kopírují do značné míry celkové preference voličské základny. Pět nejvýznamnějších faktorů (parkování, bezpečnost, nepořádek, hluk, kvalita ovzduší) je pro tento segment podstatnějších než pro jiné segmenty. Naopak ostatní problémové oblasti jsou vnímány s nižší intenzitou. Tito občané, kteří si nenašli ústřední téma, zpravidla odmítají účast ve volbách a jsou spíše levicového zaměření (viz tabulka 15).

\section{Aktivní volič}

Tento typ voliče je druhý nejpočetnější (15\%). Respondenti zdůrazňují oproti jiným segmentům potřebu dětských hřišt' a sportovišt' (viz tabulka 12), které jsou důležité pro aktivní trávení volného času. Žádná jiná problémová oblast není vnímána s nadprůměrnou intenzitou. Tento segment je tvořený především mladšími voliči ve věkových kategoriích 18 - 29 let a 30 - 39 let a respondenty s vysokoškolským vzděláním (viz tabulka 13). V Ostravě je třikrát vyšší výskyt tohoto typu voliče oproti Havířovu (viz tabulka 14). Tento typ voliče hodlá volit především ODS a Stranu zelených (viz tabulka 15).

\section{Volič ohrožený dopravou}

Tato skupina voličů (9 \%) bud' potřebuje cestovat (dostupnost MHD), nebo bydlí v okolí dopravních uzlů a je ohrožována dopravní situací, hlukem a kvalitou ovzduší. Až na parkování jiné problémové oblasti respondenti ve skutečnosti nezmínili. Demograficky segment prakticky profilovaný není. U tohoto shluku není patrný vliv věku ani vzdělání. Vyšší podíl voličů se nachází v Havířově (viz tabulka 14) a respondenti v tomto segmentu by nejspíše volili KSČM (viz tabulka 15).

\section{Nevyhraněný volič}

Podíl tohoto voliče na celkovém výběrovém souboru je velmi nízký (4\%). V tomto případě je sice nespokojenost voliče spojována s nedostatkem obchodů se základními potřebami (viz tabulka 12), ale významnost jiných vnímaných problémů prokázána nebyla. Vzhledem k omezené velikosti tohoto segmentu nejsou patrné výraznější demografické či geografické rozdíly.

Nejostřeji je demograficky profilován shluk aktivních voličů. Existence tohoto typu voliče ve výběrovém souboru závisí na věku a vzdělání. Čím nižší je věk a vyšší je vzdělání, tím pravděpodobnější je výskyt aktivního voliče (viz tabulka 13). Je to prokázáno i statistickým testováním (viz tabulka 16). Podíl univerzálních voličů zase vzrůstá s věkem. 
Tabulka 12: Vnímané problémy v okolí místa bydliště podle shluků

\begin{tabular}{|l|c|c|c|c|c|}
\hline & Univerzální & Aktivní & $\begin{array}{c}\text { Ohrožený } \\
\text { dopravou }\end{array}$ & Nevyhraněný & Celkem \\
\hline Parkování & 1,98 & 1,75 & 1,52 & 1,18 & $\mathbf{1 , 8 7}$ \\
\hline Kvalita ovzduší & 1,75 & 1,55 & 1,93 & 1,82 & $\mathbf{1 , 7 4}$ \\
\hline Hluk & 1,77 & 1,38 & 2,13 & 1,40 & $\mathbf{1 , 7 3}$ \\
\hline Nepořádek & 1,80 & 1,39 & 1,15 & 1,42 & $\mathbf{1 , 6 6}$ \\
\hline Bezpečnost & 1,82 & 1,11 & 1,10 & 1,11 & $\mathbf{1 , 6 2}$ \\
\hline Dopravní situace & 1,24 & 1,15 & $\mathbf{3 , 3 6}$ & 1,24 & $\mathbf{1 , 4 3}$ \\
\hline Nedostatek dětských hřišł & 1,13 & $\mathbf{2 , 8 9}$ & 1,22 & 1,09 & $\mathbf{1 , 4 1}$ \\
\hline Kvalita zeleně & 1,37 & 1,13 & 1,10 & 1,42 & $\mathbf{1 , 3 1}$ \\
\hline Nedostatek sportoviši & 1,08 & $\mathbf{2 , 3 3}$ & 1,15 & 1,04 & $\mathbf{1 , 2 8}$ \\
\hline Dostupnost MHD & 1,11 & 1,12 & $\mathbf{2 , 6 1}$ & 1,33 & $\mathbf{1 , 2 6}$ \\
\hline Nedostatek obchodů & 1,04 & 1,14 & 1,06 & $\mathbf{3 , 6 7}$ & $\mathbf{1 , 1 5}$ \\
\hline
\end{tabular}

Tabulka 13: Struktura shlukư (okolí místa bydliště) podle věku a vzdělání

\begin{tabular}{|l|c|c|c|c|c|c|c|c|c|}
\hline & $\mathbf{1 8 - 2 9}$ & $\mathbf{3 0 - 3 9}$ & $\mathbf{4 0 - 4 9}$ & $\mathbf{5 0 - 5 9}$ & $\mathbf{6 0 +}$ & ZV, vyučen & sš & vš & Celkem \\
\hline Univerzální & $64 \%$ & $69 \%$ & $69 \%$ & $78 \%$ & $78 \%$ & $73 \%$ & $72 \%$ & $66 \%$ & $\mathbf{7 2 \%}$ \\
\hline Aktivní & $21 \%$ & $21 \%$ & $17 \%$ & $10 \%$ & $8 \%$ & $12 \%$ & $16 \%$ & $23 \%$ & $\mathbf{1 5 \%}$ \\
\hline $\begin{array}{l}\text { Ohrožený } \\
\text { dopravou }\end{array}$ & $11 \%$ & $7 \%$ & $10 \%$ & $10 \%$ & $9 \%$ & $10 \%$ & $9 \%$ & $8 \%$ & $\mathbf{9 \%}$ \\
\hline Nevyhraněný & $4 \%$ & $3 \%$ & $4 \%$ & $3 \%$ & $5 \%$ & $4 \%$ & $3 \%$ & $3 \%$ & $\mathbf{4 \%}$ \\
\hline
\end{tabular}

Statisticky průkazný je i podíl jednotlivých typů voličů ve sledovaných městech (viz tabulka 16). V Ostravě je třikrát větší podíl aktivních než ohrožených voličů, v Havířově je tomu naopak (viz tabulka 14). V Havíŕově je i vyšší podíl univerzálních voličů.

Tabulka 14: Struktura shluků (okolí místa bydliště) podle města

\begin{tabular}{|l|c|c|c|}
\hline & Ostrava & Havĩov & Celkem \\
\hline Univerzální & $68 \%$ & $77 \%$ & $\mathbf{7 2 \%}$ \\
\hline Aktivní & $21 \%$ & $7 \%$ & $\mathbf{1 5 \%}$ \\
\hline Ohrožený dopravou & $7 \%$ & $13 \%$ & $\mathbf{9 \%}$ \\
\hline Nevyhraněný & $4 \%$ & $3 \%$ & $\mathbf{4 \%}$ \\
\hline
\end{tabular}


Tabulka 15: Struktura shluků (okolí místa bydliště) podle volební preference

\begin{tabular}{|l|r|r|r|r|r|r|r|r|r|r|r|r|r|}
\hline & ČSSD & ODS & KSČM & SZ & $\begin{array}{c}\text { KDU- } \\
\text { ČSL }\end{array}$ & VV & TOP 09 & $\begin{array}{c}\text { Jiná } \\
\text { strana }\end{array}$ & Žádná & $\begin{array}{c}\text { Nepi̊jde } \\
\text { volit }\end{array}$ & $\begin{array}{c}\text { Odmítá } \\
\text { sdělit }\end{array}$ & Neví & Celkem \\
\hline Univerzální & $74 \%$ & $66 \%$ & $75 \%$ & $67 \%$ & $80 \%$ & $87 \%$ & $78 \%$ & $71 \%$ & $69 \%$ & $78 \%$ & $59 \%$ & $72 \%$ & $\mathbf{7 2 \%}$ \\
\hline Aktivní & $14 \%$ & $21 \%$ & $10 \%$ & $23 \%$ & $10 \%$ & $3 \%$ & $11 \%$ & $24 \%$ & $22 \%$ & $7 \%$ & $22 \%$ & $14 \%$ & $\mathbf{1 5 \%}$ \\
\hline $\begin{array}{l}\text { Ohrožený } \\
\text { dopravou }\end{array}$ & $10 \%$ & $8 \%$ & $12 \%$ & $5 \%$ & $2 \%$ & $7 \%$ & $6 \%$ & & $7 \%$ & $13 \%$ & $17 \%$ & $8 \%$ & $9 \%$ \\
\hline $\begin{array}{l}\text { Nevyhra- } \\
\text { něný }\end{array}$ & $2 \%$ & $5 \%$ & $4 \%$ & $5 \%$ & $7 \%$ & $3 \%$ & $6 \%$ & $5 \%$ & $2 \%$ & $2 \%$ & $2 \%$ & $6 \%$ & $\mathbf{4 \%}$ \\
\hline Abs. počet & $\mathbf{2 6 9}$ & $\mathbf{2 5 9}$ & $\mathbf{1 3 9}$ & $\mathbf{7 8}$ & $\mathbf{4 1}$ & $\mathbf{3 0}$ & $\mathbf{1 8}$ & $\mathbf{2 1}$ & $\mathbf{4 5}$ & $\mathbf{1 5 7}$ & $\mathbf{9 2}$ & $\mathbf{9 0}$ & $\mathbf{1 2 3 9}$ \\
\hline
\end{tabular}

Mezi behaviorální segmentační proměnnou (vnímané problémy v okolí bydliště), demografickými proměnnými (věk, vzdělání, volební preference) a geografickou segmentační proměnnou (město) existuje vztah, nebot' hladina významnosti v těchto případech byla nižší než 0,05 (viz tabulka 16). Statistická závislost byla prokázána prostřednictvím $\chi^{2}$ testu, který testoval vztah mezi dvěma nominálními proměnnými. V případě věku, vzdělání, volebních preferencí a města lze tedy zamítnout nulové hypotézy a přijmout alternativní hypotézy.

Tabulka 16: Hladina významnosti pro Pearsonův $x^{2}$ koeficient (okolí bydliště)

\begin{tabular}{|l|c|}
\hline Segmentační proměnná & Hladina významnosti \\
\hline Pohlaví & 0,075 \\
\hline Věk & $\mathbf{0 , 0 0 0}$ \\
\hline Vzdělání & $\mathbf{0 , 0 3 1}$ \\
\hline Volební preference & $\mathbf{0 , 0 0 5}$ \\
\hline Město & $\mathbf{0 , 0 0 0}$ \\
\hline
\end{tabular}

Podle hodnocení významnosti problémových oblastí ve městě je možné rozdělit respondenty (komunální voliče) do tří kategorií:

\section{Univerzální volič}

Univerzální voliči tvoří nejpočetnější segment (72 \%) a nevnímají žádný z problémů až na parkování ve městě a kvalitu ovzduší ve městě intenzivněji než jiné shluky (viz tabulka 17). Naopak marginální je pro tuto skupinu voličů bezpečnost ve městě a kvalita zdravotní péče. $\mathrm{V}$ tomto segmentu je patrný větší př́klon $\mathrm{k}$ nově etablovaným politickým seskupením a stranám (viz tabulka 20). Mírně vyšší je podíl nejmladší věkové kategorie, která si zřejmě nenašla své ústřední téma (viz tabulka 18). V Havířově je tento segment zcela dominující, tvoř́ $82 \%$ (viz tabulka 19 ).

\section{Volič hledajicí zdravotní péči}

Podíl tohoto voliče ve výběrovém souboru činí $7 \%$. Jedná se především o starší voliče ve věkové kategorii 50-59 let a nad 60 let (viz tabulka 18), kteří jsou vzhledem ke zhoršujícímu se zdravotnímu stavu a vyšší frekvenci potřeby zdravotní péče na tuto oblast výrazněji 
citliví. S výjimkou hospodaření na radnici jsou všechny ostatní zkoumané problémové oblasti vnímány s nižší intenzitou než u jiných shluků. Podíl toho shluku ve sledovaných městech je stejný (viz tabulka 19).

\section{Volič citlivý na bezpečnost}

Tento segment je druhý nejpočetnější (21\%). Žádná z problémových oblastí nezajímá tento segment tak intenzivně jako bezpečnost ve městě. Demograficky není tento segment vyprofilován, vliv věku a vzdělání není statisticky významný. Třikrát více je tento segment zastoupen v Ostravě oproti Havířovu (viz tabulka 19).

Tabulka 17: Vnímané problémy města podle shluků

\begin{tabular}{|l|c|c|c|c|}
\hline & Univerzální & Zdr. péče & Bezpečnost & Celkem \\
\hline Parkování ve městě & 2,00 & 1,61 & 1,57 & $\mathbf{1 , 8 8}$ \\
\hline Kvalita ovzduší ve městě & 1,87 & 1,39 & 1,33 & $\mathbf{1 , 7 2}$ \\
\hline Bezpečnost ve městě & 1,12 & 1,18 & $\mathbf{3 , 7 7}$ \\
\hline Nepořádek ve městě & 1,63 & 1,34 & 1,45 & $\mathbf{1 , 5 7}$ \\
\hline $\begin{array}{l}\text { Dopravní situace } \\
\text { ve městě }\end{array}$ & 1,68 & 1,11 & 1,28 & $\mathbf{1 , 5 5}$ \\
\hline Hluk ve městě & 1,59 & 1,26 & 1,45 & $\mathbf{1 , 5 4}$ \\
\hline Kvalita zdravotní péče & 1,09 & $\mathbf{3 , 6 1}$ & 1,28 & $\mathbf{1 , 3 1}$ \\
\hline Zeleň ve městě & 1,35 & 1,06 & 1,12 & $\mathbf{1 , 2 5}$ \\
\hline Korupce & 1,30 & 1,16 & 1,11 & $\mathbf{1 , 2 3}$ \\
\hline Odchod lidí z města & 1,22 & 1,33 & 1,24 & $\mathbf{1 , 2 2}$ \\
\hline Hospodaření radnice & 1,22 & 1,47 & 1,12 & $\mathbf{1 , 2 1}$ \\
\hline Nedostatek hřšł́ ve městě & 1,23 & 1,24 & 1,13 & \\
\hline
\end{tabular}

Demograficky strukturovaný profil není v př́ípadě hodnocení města jako celku tak čitelný jako $\mathrm{v}$ případě problémů vnímaných $\mathrm{v}$ okolí bydliště respondenta. Pouze u shluku voličů hledajících zdravotní péči je patrná kategorizace podle věku (viz tabulka 18).

Tabulka 18: Struktura shluků (město) podle věku a vzdělání

\begin{tabular}{|l|r|r|r|r|r|r|r|r|r|}
\hline & $\mathbf{1 8 - 2 9}$ & $\mathbf{3 0 - 3 9}$ & $\mathbf{4 0 - 4 9}$ & $\mathbf{5 0 - 5 9}$ & $\mathbf{6 0 +}$ & $\mathbf{Z V}$, vyučen & $\mathbf{s s ̌}$ & vš & Celkem \\
\hline Univerzální & $76 \%$ & $70 \%$ & $74 \%$ & $70 \%$ & $69 \%$ & $72 \%$ & $71 \%$ & $73 \%$ & $\mathbf{7 2 \%}$ \\
\hline Zdravotní péče & $4 \%$ & $6 \%$ & $8 \%$ & $7 \%$ & $11 \%$ & $8 \%$ & $7 \%$ & $6 \%$ & $\mathbf{7 \%}$ \\
\hline Bezpečnost & $20 \%$ & $23 \%$ & $18 \%$ & $23 \%$ & $20 \%$ & $21 \%$ & $22 \%$ & $20 \%$ & $\mathbf{2 1 \%}$ \\
\hline
\end{tabular}

Vyšší citlivost voličů na problematiku bezpečnosti ve městě Ostravě vyvolala rozdíly v podílu univerzálních voličů v obou sledovaných městech (viz tabulka 19). 
Tabulka 19: Struktura shluků (město) podle města

\begin{tabular}{|l|c|c|c|}
\hline & Ostrava & Havĩ̃ov & Celkem \\
\hline Univerzální & $65 \%$ & $82 \%$ & $\mathbf{7 2 \%}$ \\
\hline Zdravotní péče & $7 \%$ & $7 \%$ & $\mathbf{7 \%}$ \\
\hline Bezpečnosł & $28 \%$ & $10 \%$ & $\mathbf{2 1 \%}$ \\
\hline
\end{tabular}

Rozdíly ve struktuře typů voličů podle volebních preferencí jsou patrné u politických stran s nižším voličským potenciálem (viz tabulka 20 ). Na výsledky tak má spíše vliv absolutní počet členů favorizujících jednotlivé politické strany než rozdíly způsobené vlastní intenzitou vnímání problémových oblastí.

Tabulka 20: Struktura shluků (město) podle volební preference

\begin{tabular}{|l|r|r|r|r|r|r|r|r|r|r|r|r|r|}
\hline & ČSSD & ODS & KSČM & SZ & $\begin{array}{c}\text { KDU- } \\
\text { ČSL }\end{array}$ & VV & TOP 09 & $\begin{array}{c}\text { Jiná } \\
\text { strana }\end{array}$ & Žádná & $\begin{array}{c}\text { Nepůjde } \\
\text { volit }\end{array}$ & $\begin{array}{c}\text { Odmítá } \\
\text { sdělit }\end{array}$ & Neví & Celkem \\
\hline Univerzální & $70 \%$ & $71 \%$ & $72 \%$ & $59 \%$ & $54 \%$ & $87 \%$ & $83 \%$ & $90 \%$ & $58 \%$ & $76 \%$ & $84 \%$ & $74 \%$ & $\mathbf{7 2 \%}$ \\
\hline $\begin{array}{l}\text { Zdravotní } \\
\text { péče }\end{array}$ & $8 \%$ & $7 \%$ & $9 \%$ & $8 \%$ & $12 \%$ & $10 \%$ & $6 \%$ & & $7 \%$ & $4 \%$ & $4 \%$ & $9 \%$ & $\mathbf{7 \%}$ \\
\hline Bezpečnost & $22 \%$ & $22 \%$ & $19 \%$ & $33 \%$ & $34 \%$ & $3 \%$ & $11 \%$ & $10 \%$ & $36 \%$ & $20 \%$ & $12 \%$ & $17 \%$ & $\mathbf{2 1 \%}$ \\
\hline Abs. počet & $\mathbf{2 6 9}$ & $\mathbf{2 5 9}$ & $\mathbf{1 3 9}$ & $\mathbf{7 8}$ & $\mathbf{4 1}$ & $\mathbf{3 0}$ & $\mathbf{1 8}$ & $\mathbf{2 1}$ & $\mathbf{4 5}$ & $\mathbf{1 5 7}$ & $\mathbf{9 2}$ & $\mathbf{9 0}$ & $\mathbf{1 2 3 9}$ \\
\hline
\end{tabular}

Rovněž lze prokázat, že existuje vztah mezi behaviorální segmentační proměnnou (vnímané problémy ve městě), demografickou proměnnou (volební preference) a geografickou segmentační proměnnou (město), nebot' hladina významnosti v těchto případech byla nižší než 0,05 (viz tabulka 21). Statistická závislost byla opět ověřena prostřednictvím $\chi^{2}$ testu. Nulové hypotézy byly zamítnuty u volebních preferencí a města, v němž šetření probíhalo.

Tabulka 21: Hladina významnosti pro Pearsonův $X^{2}$ koeficient (město)

\begin{tabular}{|l|c|}
\hline Segmentační proměnná & Hladina významnosti \\
\hline Pohlaví & 0,309 \\
\hline Věk & 0,097 \\
\hline Vzdělání & 0,964 \\
\hline Volební preference & $\mathbf{0 , 0 0 4}$ \\
\hline Město & $\mathbf{0 , 0 0 0}$ \\
\hline
\end{tabular}

\section{Typologie voličů}

V předchozí podkapitole byly vydefinovány shluky voličů podle jejich názoru na vnímané problémy v okolí bydliště a ve městě. Prostřednictvím testování rozdílů v průměrech párových faktorů (viz tabulka 8) bylo identifikováno, že existují diference v názorech respondentů na identický problém v okolí bydliště a ve městě. To se odrazilo i v rozdílných výsledcích typologie voličů týkající se okolí bydliště respondenta a města. 
Typologie voličů vztažená k vnímání problémů v okolí bydliště je vhodná pro komunální volby probíhající v jednotlivých městských obvodech. Strategie v municipálních volbách musí reflektovat vnímání problémových oblastí jak v blízkosti bydliště, tak ve městě. Vzniká otázka, jaký je vztah mezi klasifikací typů (shluků) pro okolí bydliště a města. Výsledky ukazují, že vztah mezi klasifikovanými typy existuje (viz tabulka 22). Největší podíl ve výběrovém souboru tvoří voliči, kteří jsou klasifikováni jako univerzální jak pro okolí bydliště, tak pro město $(50 \%)$.

Tabulka 22: Matice typů voličů pro okolí bydliště a město

\begin{tabular}{|l|c|c|c|c|}
\hline & Univerzální & Zdr. péče & Bezpečnost & Celkem \\
\hline Univerzální & $50 \%$ & $5 \%$ & $16 \%$ & $\mathbf{7 2 \%}$ \\
\hline Aktivní & $11 \%$ & $1 \%$ & $3 \%$ & $\mathbf{1 5 \%}$ \\
\hline $\begin{array}{l}\text { Ohrožený } \\
\text { dopravou }\end{array}$ & $8 \%$ & $1 \%$ & $1 \%$ & $\mathbf{9 \%}$ \\
\hline Nevyhraněný & $2 \%$ & $1 \%$ & $1 \%$ & $\mathbf{4 \%}$ \\
\hline Celkem & $\mathbf{7 2 \%}$ & $\mathbf{7 \%}$ & $\mathbf{2 1 \%}$ & $\mathbf{1 0 0 \%}$ \\
\hline
\end{tabular}

Statisticky průkazný vztah mezi typologií voličů podle okolí bydliště a města je potvrzen prostřednictvím Pearsonova koeficientu, který je na hladině významnosti 95 \% nižší než 0,05 (viz tabulka 23).

Tabulka 23: Statistické testování vztahu mezi typy voličů pro okolí bydliště a město

Test Chi-kvadrátu

\begin{tabular}{|l|c|c|c|}
\hline & Hodnota & Stupeň volnosti & p \\
\hline Pearson Chi-kvadrát & 15,068 & 6 & 0,02 \\
\hline N (počet validních prípad̊̊) & 1239 & & \\
\hline
\end{tabular}

Na základě kombinace výsledků z tabulky 22 lze vytvořit model (viz obrázek 1), který zobrazuje výsledky typologie jak pro okolí bydliště, tak pro město.

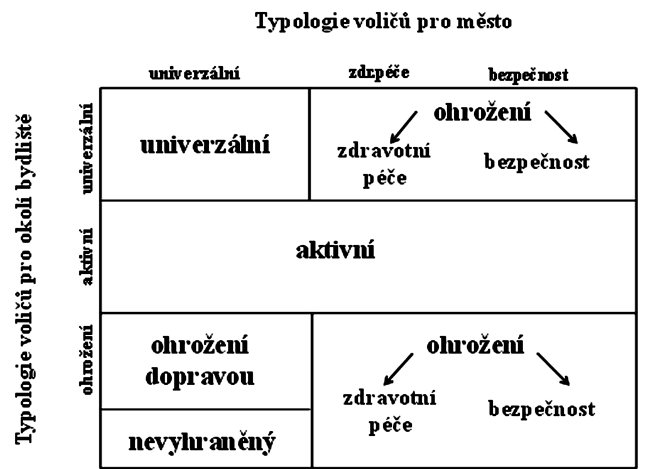

Obrázek 1: Model typologie voličů pro okolí bydliště a město 
Z modelu vyplývá, že lze definovat tř́i základní typy voličů:

\section{Univerzální volič}

Univerzální volič představuje průnik typu voliče, který shodně nahlíží na problémy v okolí bydliště i ve městě. Tento typ voliče je nejpočetnější ze všech shluků, nebot' tvoří 50 \% výběrového souboru (viz tabulka 24 ). Respondenti hodnotí jako významné všechny problémové oblasti v okolí bydliště i ve městě, které se v celkovém hodnocení objevily na předních pozicích (parkování, kvalita ovzduší, nepořádek, hluk). Tento segment není plně vyprofilovaný, i když je patrný mírně vyšší podíl respondentů starších 50 let (viz tabulka 25).

Tabulka 24: Struktura typů voličủ (základní verze)

\begin{tabular}{|l|c|c|}
\hline & Abs. četnost & Rel. četnost \\
\hline Univerzální & 624 & $50 \%$ \\
\hline Aktivní & 190 & $15 \%$ \\
\hline Ohrožený & 380 & $31 \%$ \\
\hline Nevyhraněný & 45 & $4 \%$ \\
\hline Celkem & $\mathbf{1 2 3 9}$ & $\mathbf{1 0 0 \%}$ \\
\hline
\end{tabular}

Tabulka 25: Typologie voličů podle věku a vzdělání

\begin{tabular}{|l|c|c|c|c|c|c|c|c|c|}
\hline & $\mathbf{1 8 - 2 9}$ & $\mathbf{3 0 - 3 9}$ & $\mathbf{4 0 - 4 9}$ & $\mathbf{5 0 - 5 9}$ & $\mathbf{6 0 +}$ & $\begin{array}{c}\text { ZV, } \\
\text { vyučen }\end{array}$ & $\mathbf{s s ̌}$ & vš & Celkem \\
\hline Univerzální & $47 \%$ & $49 \%$ & $48 \%$ & $54 \%$ & $54 \%$ & $51 \%$ & $50 \%$ & $46 \%$ & $\mathbf{5 0 \%}$ \\
\hline Aktivní & $21 \%$ & $21 \%$ & $17 \%$ & $10 \%$ & $8 \%$ & $12 \%$ & $16 \%$ & $23 \%$ & $\mathbf{1 5 \%}$ \\
\hline Ohrožený & $28 \%$ & $28 \%$ & $31 \%$ & $33 \%$ & $34 \%$ & $32 \%$ & $30 \%$ & $27 \%$ & $\mathbf{3 1 \%}$ \\
\hline Nevyhraněný & $4 \%$ & $3 \%$ & $4 \%$ & $3 \%$ & $5 \%$ & $4 \%$ & $3 \%$ & $3 \%$ & $\mathbf{4 \%}$ \\
\hline
\end{tabular}

\section{Aktivní volič}

Aktivní voliči jsou vymezeni pouze z pohledu typologie založené na vnímání problémových oblastí v okolí bydliště. Zdůrazňují oproti jiným segmentům potřebu dětských hřišt' a sportovišt', které jsou důležité pro aktivní trávení volného času. Tento segment tvoří $15 \%$ respondentů (viz tabulka 24). Struktura tohoto segmentu závisí na věku a vzdělání. Tendence $\mathrm{k}$ tomuto typu roste se vzděláním a klesá s věkem (viz tabulka 25). Aktivními voliči jsou především respondenti ve věku do 39 let a vysokoškolští respondenti a je pro ně typická pravicová orientace (viz tabulka 26). Výskyt tohoto typu voliče je v Ostravě třikrát vyšší než v Havírově (viz tabulka 28). 
Tabulka 26: Typologie voličů podle volební preference

\begin{tabular}{|l|r|r|r|r|r|r|r|r|r|r|r|r|r|}
\hline & ČSSD & ODS & KSČM & SZ & $\begin{array}{c}\text { KDU- } \\
\text { ČSL }\end{array}$ & VV & TOP 09 & $\begin{array}{c}\text { Jiná } \\
\text { strana }\end{array}$ & Žádná & $\begin{array}{c}\text { Nepưjde } \\
\text { volit }\end{array}$ & $\begin{array}{c}\text { Odmítá } \\
\text { sdělit }\end{array}$ & Neví & Celkem \\
\hline Univerzální & $51 \%$ & $46 \%$ & $53 \%$ & $42 \%$ & $37 \%$ & $77 \%$ & $67 \%$ & $62 \%$ & $36 \%$ & $58 \%$ & $50 \%$ & $51 \%$ & $\mathbf{5 0 \%}$ \\
\hline Aktivní & $14 \%$ & $21 \%$ & $10 \%$ & $23 \%$ & $10 \%$ & $3 \%$ & $11 \%$ & $24 \%$ & $22 \%$ & $7 \%$ & $22 \%$ & $14 \%$ & $\mathbf{1 5 \%}$ \\
\hline Ohrožený & $32 \%$ & $29 \%$ & $34 \%$ & $29 \%$ & $46 \%$ & $17 \%$ & $17 \%$ & $10 \%$ & $40 \%$ & $33 \%$ & $26 \%$ & $29 \%$ & $\mathbf{3 1 \%}$ \\
\hline Nevyhraněný & $2 \%$ & $5 \%$ & $4 \%$ & $5 \%$ & $\mathbf{7} \%$ & $3 \%$ & $6 \%$ & $5 \%$ & $2 \%$ & $2 \%$ & $2 \%$ & $6 \%$ & $\mathbf{4 \%}$ \\
\hline Abs. počet & $\mathbf{2 6 9}$ & $\mathbf{2 5 9}$ & $\mathbf{1 3 9}$ & $\mathbf{7 8}$ & $\mathbf{4 1}$ & $\mathbf{3 0}$ & $\mathbf{1 8}$ & $\mathbf{2 1}$ & $\mathbf{4 5}$ & $\mathbf{1 5 7}$ & $\mathbf{9 2}$ & $\mathbf{9 0}$ & $\mathbf{1 2 3 9}$ \\
\hline
\end{tabular}

\section{Ohrožený volič}

Ohrožení voliči jsou druhým nejpočetnějším shlukem. Jejich podíl činí 30 \%. Voliči pocit’ují ohrožení jednak v okolí bydliště, což je vyvoláno zejména dopravou a následky z toho vyplývajícími (hluk, kvalita ovzduší), jednak v problémových oblastech, které jsou vztaženy na celé město (bezpečnost, zdravotní péče). To je odlišeno v tabulce 28 i obrázku 1 . Demografický profil tohoto segmentu není tak výrazný jako v př́ípadě aktivních voličů, ačkoliv vyšší citlivost na zajištění zdravotní péče vykazují respondenti ve věku nad 50 let (viz tabulka 18). Vyšší podíl ohrožených voličů je opět v Ostravě (viz tabulka 28).

Tabulka 27: Struktura typů voličů (rozšĩrená verze)

\begin{tabular}{|l|c|c|}
\hline & Abs. četnost & Rel. četnost \\
\hline Univerzální & 624 & $50 \%$ \\
\hline Aktivní & 190 & $15 \%$ \\
\hline Ohrožený v místě bydliště & 117 & $9 \%$ \\
\hline Ohrožený ve městě & 263 & $22 \%$ \\
\hline Nevyhraněný & 45 & $4 \%$ \\
\hline Celkem & $\mathbf{1 2 3 9}$ & $\mathbf{1 0 0 \%}$ \\
\hline
\end{tabular}

Tabulka 28: Typologie voličů podle města

\begin{tabular}{|l|c|c|c|}
\hline & Ostrava & Havĩov & Celkem \\
\hline Univerzální & $42 \%$ & $64 \%$ & $50 \%$ \\
\hline Aktivní & $21 \%$ & $7 \%$ & $15 \%$ \\
\hline Ohrožený & $33 \%$ & $27 \%$ & $31 \%$ \\
\hline Nevyhraněný & $4 \%$ & $3 \%$ & $4 \%$ \\
\hline
\end{tabular}

Nevyhraněný volič tvoří pouze $4 \%$ výběrového souboru, proto není potřeba se tímto segmentem zabývat.

Tabulka 24 a 27 ukazují strukturu typů voličů na základě jejich vnímání problémových oblastí. Tabulka 27 představuje rozšiřrenou verzi, která rozlišuje mezi ohrožením, které je vnímáno v okolí bydliště, a ohrožením, které je vnímáno ve městě. 
Mezi typologií voličů a demografickými proměnnými (věk, vzdělání, volební preference) a geografickou segmentační proměnnou (město) existuje vztah, nebot' hladina významnosti $v$ těchto př́ípadech byla nižší než 0,05 (viz tabulka 29). Statistická závislost byla prokázána prostřednictvím $\chi^{2}$ testu, který testoval vztah mezi dvěma nominálními proměnnými. V př́ípadě věku, vzdělání, volebních preferencí a města lze tedy zamítnout nulové hypotézy a přijmout alternativní hypotézy.

Tabulka 29: Hladina významnosti pro Pearsonův $\chi^{2}$ koeficient (struktura typů voličů)

\begin{tabular}{|l|c|}
\hline Segmentační proměnná & Hladina významnosti \\
\hline Pohlaví & 0,124 \\
\hline Věk & $\mathbf{0 , 0 0 3}$ \\
\hline Vzdělání & $\mathbf{0 , 0 3 3}$ \\
\hline Volební preference & $\mathbf{0 , 0 0 2}$ \\
\hline Město & $\mathbf{0 , 0 0 0}$ \\
\hline
\end{tabular}

\section{Závěr}

Předložený příspěvek klasifikuje voliče komunálních voleb podle vnímání problémových situací v okolí bydliště a ve městě. Na základě shlukování je možné nalézt shluky respondentů (voličů), kteří vnímají určité problémy intenzivněji než jiné segmenty respondentů (voličů).

Př́spěvek prokázal, že pro segmentaci voličů pro komunální volby je vhodné identifikovat problémové oblasti zvláśst' pro okolí bydliště a zvlášt' pro město. To platí nejen s ohledem na to, že některé problémové oblasti jsou typické pouze pro okolí bydliště (dostupnost MHD, hluk, nedostatek obchodů) a jiné pro město (odchod lidí z města, korupce, hospodaření radnice, kvalita zdravotní péče). Test párových rozdílů (viz tabulka 7) u faktorů, které byly zkoumány souběžně jak pro okolí bydliště, tak pro město ukázal, že stejný faktor (např́klad bezpečnost) je jinak posuzovaný v daném obvodu a jinak ve městě.

Pro úspěšnost typologie je důležitý proces shlukování a nastavení jeho citlivosti prostřednictvím definovaných počtů shluků. Vyšší počet shluků na jedné straně znamená lépe propracovaný demografický profil voličů, na druhé straně se s počtem shluků snižuje absolutní počet členů ve shluku, což bude mít vliv na efektivnost procesu segmentace a komunikace. Výsledky prokázaly, že 3 až 4 shluky představují ideální velikost pro typologii voličů.

Bez ohledu na posuzované prostředí lze nalézt tři základní typy voličů: voliče univerzální, aktivní a ohrožené (viz obrázek 1). Univerzální voliči tvoří ve všech klasifikacích největší podíl. Nejsou vyhraněni ve vnímání problémových situací a jejich pozornost se soustřed'uje na problémy hodnocené všemi respondenty jako nejvýznamnější. Na tento typ voliče se koncentruje zájem nejsilnějších politických stran. Avšak univerzální voliči preferují spíše nová politická seskupení nebo patř́ mezi nerozhodnuté voliče. Přesto musí nejsilnější politické strany usilovat o tento typ voliče, nebot' ztráta jeho preferencí bude znamenat neúspěch v komunálních volbách. 
Ohrožení voliči zpravidla velmi intenzivně vnímají jednu z problémových oblastí (například dopravní situaci, zdravotní péči či bezpečnost) a jejich uspokojení může znamenat volební úspěch. Tento typ voliče nemůže zaručit politické straně masovou podporu, nebot' intenzita výskytu jednotlivého problému nepřesahuje $10 \%$ voličské základny, avšak může voličskou základnu rozšíriit. Vzhledem k tomu, že u tohoto typu voliče hraje roli věk, je tento segment dobře identifikovatelný a ovlivnitelný komunikačními nástroji.

Aktivní voliči jsou rovněž vymezeni preferencí některé z problémových oblastí, která však $\mathrm{v}$ tomto př́padě souvisí $\mathrm{s}$ aktivním trávením volného času, a proto je spíše vztažena k okolí bydliště. Tento typ voliče je nejlépe demograficky profilován (mladší, vzdělanější) a je orientován na pravicové nebo středové politické strany.

Analýza prokázala souvislost typologie voličů s demografickými, respektive geografickými proměnnými, což napomáhá jednodušší identifikaci voličské základny a přizpůsobení mediálních nástrojů. Klíčovými parametry jsou věk a vzdělání, zatímco vliv pohlaví na vnímání problémových oblastí a typologii prokázán nebyl. $Z$ výzkumu rovněž vyplynuly podstatné rozdíly ve struktuře typů voličů podle zkoumaného města.

\section{Literatura}

AAKER, A. David. Strategic Market Management. New York: John Wiley and Sons, 2007. 322 s. ISBN 9780470056233.

BARNES, H. Samuel. Partisanship and Electoral Behavior. In Jennings, M. K.; Van Deth, J. W. (eds.) Continuities in Political Action. Berlin: De Gruyter, 1989, s. 235-274. ISBN 3110120240.

BERGSTROM, C. Theodore a Robert P. GOODMAN. Private Demands for Public Goods. The American Economic Review, 1973, č. 63, s. 280-296. ISSN 0002-8282.

BINSTOCK, H. Robert a Jill QUADAGNO. Aging and Politics. In Binstock, R. H., George, L. K. (eds.) Handbook of Aging and the Social Sciences. 7th ed. San Diego: Academic Press, 2011, s. 333-351. ISBN 978-0-12-380880-6.

BOCK, Timothy a Mark D. UNCLES. A Taxonomy of Differences between Consumers for Market Segmentation. International Journal of Research in Marketing, 2002, č. 19, s. 215-224. ISSN: 0167-8116.

BONOMA, V. Thomas a Benson P. SHAPIRO. Evaluating Market Segmentation Approaches. Industrial Marketing Management, 1984, roč. 13, č. 4, s. 258-267. ISSN 0019-8501.

BRUNNER, J. Eric a Stephen L. ROSS. Is the Median Voter Decisive? Evidence from Referenda Voting Patterns. Journal of Public Economics, 2010, č. 94, s. 898-910. ISSN 0047-2727.

EPPLE, Dennis a Richard E. ROMANO. Public Provision of Private Goods. Journal of Political Economy, 1996, č. 104, s. 57-84. ISSN 0022-3808.

EPPLE, Dennis a Glenn J. PLATT. Equilibrium and Local Redistribution in an Urban Economy when Households Differ in Both Preferences and Incomes. Journal of Urban Economics, 1998, č. 43, s. 23-51. ISSN 0094-1190.

EPPLE, Dennis a Holger SIEG. Estimating Equilibrium Models of Local Jurisdictions. Journal of Political Economy, 1999, č. 107, s. 645-681. ISSN 0022-3808.

EPPLE, Dennis; ROMER, Thomas a Holger SIEG. Interjurisdictional Sorting and Majority Rule: An Empirical Analysis. Econometrica, 2001, č. 69, s. 1437-1465. ISSN 1468-0262.

GLENN, D. Norval a Ted HEFNER. Further Evidence on Aging and Party Identification. Public Opinion Quarterly, 1972, č. 36, s. 31-47. ISSN 0033-362X. 
GOERRES, Achim. The Grey Vote: Determinants of Older Voters' Party Choice in Britain and West Germany. Electoral Studies, 2008, č. 27, s. 285-304. ISSN 0261-3794.

HARROP, Martin. Political Marketing. Parliamentary Affairs, 1990, č. 43, s. 277-291. ISSN 0031-2290.

KAHNEMAN, Daniel a Amos TVERSKY. Subjective Probability: A Judgment of Representativeness. Cognitive Psychology, 1972, č. 3, s. 430-454. ISSN 0010-0285.

KAHNEMAN, Daniel a Amos TVERSKY. Judgement under Uncertainty: Heuristics and Biases. Science, 1974, vol. 185, č. 4157, s. 1124-1131. ISSN 0036-8075.

KOSMIDIS, Spyros a Georgios XEZONAKIS. The Undecided Voters and the Economy: Campaign Heterogeneity in the 2005 British General Election. Electorial studies, 2010, č. 29, s. 604-616. ISSN 0261-3794.

KUO, Ren Jieh; HO, M. Loc a Chung Ming HU. Cluster Analysis in Industrial Market Segmentation through Artificial Neural Network. Computers\&Industrial Engineering, 2002, č. 42, s. 391-399. ISSN 0360-8352.

MALHOTRA, K. Naresh a David F. BIRKS. Marketing Research. An Applied Approach. London: Prentice Hall, 2006. 754 s. ISBN 0-273-69530-4.

O'LEARY, Ray a Ian IREDALE. The Marketing Concept: Quo Vadis? European Journal of Marketing, 1976, roč. 10, č. 3, s. 146-157. ISSN 0309-0566.

SNIDERMAN, M. Paul; BRODY, A. Richard a Philip E. TETLOCK. Reasoning and Choice. Exploration in Political Psychology. New York: Cambridge University Press, 1991. 306 s. ISBN 0521402557.

TILEY, R. James. Libertarian-Authoritarian Value Change in Britain, 1974-2001. Political Studies. 2005, č. 53, s. 442-453. ISSN 1467-9248.

YORKE, A. David a Sean A. MEEHAN. ACORN in the Political Marketplace. European Journal of Marketing, 1986, roč. 20, č. 8, s. 63-76. ISSN 0309-0566.

WEDEL, Michel a Wagner Antonio KAMAKURA. Market Segmentation: Conceptual and Methodological Foundations. Dodrecht: Kluwer Academic Publishers, 2000. 332 s. ISBN 0-7923-8635-3.

\section{Autor}

Doc. Ing. Vojtěch Spáčil, CSc. je vedoucím katedry marketingu a obchodu na Ekonomické fakultě VŠB-TU, kde přednáší předměty Marketingové řízení a Business Marketing. Je co-editorem časopisu Ekonomické revue - CEREI. Je členem mezinárodní profesní asociace pro výzkum trhu a veřejného mínění ESOMAR.

Kontakt: Katedra marketingu a obchodu, Ekonomická fakulta, VŠB-Technická univerzita, Sokolská třída 33, 70121 Ostrava; e-mail: vojtech.spacil@vsb.cz 